Original Article

Plant Genetics

\title{
Genome composition and pollen viability of Jatropha (Euphorbiaceae) interspecific hybrids by Genomic In Situ Hybridization (GISH)
}

\author{
Rosilda Cintra de Souza ${ }^{1,2}$ (iD, Daniela de Argollo Marques ${ }^{3}$ (iD, Marcel Mamede de Carvalho Filho ${ }^{3}$, Ana \\ Rafaela da Silva Oliveira ${ }^{1}$ iD, Walter José Siqueira ${ }^{3}$ iD, Ana Maria Benko-Iseppon ${ }^{1}$ iD and Ana Christina \\ Brasileiro-Vidal ${ }^{1,2}$ iD \\ ${ }^{1}$ Universidade Federal de Pernambuco, Departamento de Genética, Recife, PE, Brazil. \\ ${ }^{2}$ Universidade Federal Rural de Pernambuco, Departamento de Agronomia, Recife, Pernambuco, Brazil. \\ ${ }^{3}$ Instituto Agronômico de Campinas, Campinas, São Paulo, Brazil.
}

\begin{abstract}
Interspecific hybridization is required for the development of Jatropha curcas L. improved cultivars, due to its narrow genetic basis. The present study aimed to analyze the parental genomic composition of $\mathrm{F}_{1}$ and $\mathrm{BC}_{1} \mathrm{~F}_{1}$ generations derived from interspecific crosses (J. curcas/J. integerrima and J. curcas/J. multifida) by GISH (Genomic In Situ Hybridization), and the meiotic index and pollen viability of $F_{1}$ hybrids. In $F_{1}$ cells from both hybrids, 11 chromosomes of each parental was observed, as expected, but chromosome rearrangement events could be detected using rDNA chromosome markers, suggesting unbalanced cells. In the $\mathrm{BC}_{1} \mathrm{~F}_{1}$, both hybrids had 22 chromosomes, suggesting that only $n=11$ gametes were viable in the next generation. However, GISH allowed the identification of three and two alien chromosomes in J. curcas//J. integerrima and J. curcas//J. multifida $\mathrm{BC}_{1} \mathrm{~F}_{1}$ hybrids, respectively, suggesting a preferential transmission of $J$. curcas chromosomes for both hybrids. Pollen viability in $F_{1}$ hybrids derived from J. curcas/J. integerrima crosses were higher (82-83\%) than those found for J. curcas/J. multifida (68\%), showing post-meiotic problems in these last hybrids, with dyads, triads, polyads, and micronuclei as post-meiosis results. The here presented cytogenetic characterization of interspecific hybrids and their backcross progenies can contribute to the selection of the best genotypes for future assisted breeding of $\mathrm{J}$. curcas.
\end{abstract}

Keywords: Interspecific crosses, Jatropha integerrima, J. multifida, physic nut, plant breeding.

Received: April 05, 2019; Accepted: November 10, 2019.

\section{Introduction}

The incorporation of renewable energy sources in the global energetic matrix is essential to ease the current and future energy crisis, considering the future shortage and the direct and indirect negative impact of petroleum and its derivatives to the environment, as pollutants. Known as physic nut, Jatropha curcas L. (Euphorbiaceae) has been considered one of the most promising oilseed plants for biodiesel and biokerosene production due to its productivity (yield ranges up to $3000 \mathrm{~kg}$ seeds/ha), high seed oil content and quality, reaching 40 to 50\% (Sinha et al., 2016), besides its ability to thrive in lands not suited to food crops (Carels, 2013; Montes and Melchinger, 2016). Despite the promises, $J$. curcas is an undomesticated species with no available stable and commercial cultivars that can make the energy culture feasible. Hence, there is a demand for con-

Send correspondence to Ana Christina Brasileiro-Vidal. Laboratório de Genética e Biotecnologia Vegetal, Departamento de Genética, Centro de Biociências, Universidade Federal de Pernambuco, Cidade Universitária, Av. Professor Moares Rego, s/ n, 50732-970, Recife, PE, Brazil. E-mail: brasileirovidal.ac@gmailcom tinued investment in genetic breeding research (de Argollo Marques et al., 2013). Additionally, J. curcas has been susceptible to numerous pests, such as white mite (Polyphagotarsonemus latus), bed bug (Pachycoris torridus), and green leafhopper (Empoasca spp.), besides several fungal diseases. Interspecific hybridization is a promising strategy for genetic enhancement of resistance of $J$. curcas against many biotic stresses (de Argollo Marques et al., 2013; Sujatha, 2013).

The establishment, characterization and suitable use of a germplasm bank representing the genetic variability of the species (core collection) are essential for the success of a breeding program (Díaz et al., 2017). Genetic diversity studies using morphological (Montes Osorio et al., 2014; Pazeto et al., 2015) or/and molecular markers (Basha and Sujatha, 2007; Tanya et al., 2011; Sudheer et al., 2011; Montes et al., 2014; Pecina-Quintero et al., 2014) have reported narrow diversity in J. curcas germplasm with exception of some studied Mexican accessions (probable center of origin of physic nut) (Santos et al., 2016; Li et al., 2017). 
Generation of cultivars with higher productivity, increased oil content and quality, production uniformity, and resistance to biotic and abiotic stresses has been achieved by interspecific breeding (Sujatha, 2013). Congener species exhibit large genetic diversity, with several interesting agronomic traits (Popluechai et al., 2009; de Argollo Marques et al., 2013; Díaz et al., 2017). The closely related evergreen shrub J. integerrima (Sudheer Pamidiamarri et al., 2008) ( $2 n=2 x=22$, Marinho et al., 2018), for instance, carries traits not found in $J$. curcas, such as setting profuse flowers with uniform blooming on the same inflorescence, presence of woody stem and branches, besides dwarf varieties (Laosatit et al., 2014, One et al., 2014). Additionally, $J$. integerrima presents biotic stress tolerance, with maximum resistance against foliage feeders in terms of larval mortality, besides feeding cessation with or without pupation (Sujatha, 2013). On the other hand, the also diploid $J$. multifida $(2 n=2 x=22$, Marinho et al., 2018) presents seeds about $30 \%$ larger and with a higher oil content $(50 \%)$ than J. curcas (23-38\%) (Sujatha, 1996; Banerji et al., 1985). The energetic value of J. multifida oil (57.1 MJ/kg) is the highest among the studied Jatropha species, surpassing values observed for J. glandulifera Roxb. (47.2 MJ/kg), J. gossypiifolia L. $(42.2 \mathrm{MJ} / \mathrm{kg})$ and J. curcas $(39.8-41.8$ $\mathrm{MJ} / \mathrm{kg}$ ) (Jones and Miller, 1991).

Jatropha curcas is a monoecious species with unisexual flowers (Montes and Melchinger, 2016); xenogamic (Divakara et al., 2010; de Argollo Marques et al., 2013); self-compatible (Chang-Wei et al., 2007; Brasileiro et al., 2012), and diploid ( $2 n=2 x=22)$, as well as most congeners species (Carvalho et al., 2008; Sasikala and Paramathma, 2010; Marinho et al., 2018). These traits allow crosses between Jatropha species, although with limited success due to either pre- or post-zygotic barriers (Moreira et al., 2013), which can be overcome using in vitro embryo rescue technique (Laosatit et al., 2017). However, several successful crosses have been reported, for instance, between J. curcas and $J$. integerrima, aiming at shorter plants, higher seed oil yield, resistance to diseases, woody biomass, etc (Sujatha and Prabakaran, 2003; Parthiban et al., 2009; Muakrong et al., 2014; One et al., 2014).

Other difficulties may be related to problems in the meiotic and post-meiotic behavior of these hybrids, which can generate plants of little or no agronomic value, with low fertility or sterility due to reduction in the production of viable pollens and seeds. Thus, the evaluation of pollen viability is essential for the success of interspecific crosses (Pagliarini, 2000; Souza et al., 2017), including Jatropha species. In addition, Genomic In Situ Hybridization (GISH) studies of interspecific hybrids can provide relevant information for breeding programs, allowing differentiation of the parental genomes in hybrid cells and the detection of non-homologous recombination, which is fundamental for the introgression of new traits into material derived from interspecific hybrids. GISH analyses may facilitate the choice of promising hybrids during the early stages of breeding through the detection of alien chromatin. This characterization allows the planning of crosses, aiming to maximize the segregation for the recovery of superior genotypes (Fukuhara et al., 2016; Liu et al., 2017; Ramzan et al., 2017; Grewal et al., 2018;).

Considering the limited knowledge regarding chromosome behavior, pollen viability and fertility of Jatropha interspecific hybrids and their progenies, the present work aimed to understand the chromosome behavior in $\mathrm{F}_{1}$ hybrids of $J$. curcas/J. integerrima and J. curcas/J. multifida and their respective $\mathrm{BC}_{1} \mathrm{~F}_{1}$ backcrosses, inferring on their parental genomic composition, meiotic indexes and pollen viability. The presented results will facilitate the design of breeding programs for the improvement of wild trait introgressions to J. curcas.

\section{Materials and Methods}

\section{Plant material}

Jatropha curcas and two congener species, $J$. multifida, and $J$. integerrima were used in interspecific crosses. Their $\mathrm{F}_{1}$ hybrids and backcrosses $\left(\mathrm{BC}_{1} \mathrm{~F}_{1}\right)$ were used to analyze the parental genomic composition by GISH, also evaluating post-meiotic behavior and pollen viability. Parents, crosses and respective accessions numbers are presented in Tables 1 and 2.

\section{$\mathrm{F}_{1}$ and $\mathrm{BC}_{1} \mathrm{~F}_{1}$ hybrids}

Hybridizations were performed according to Rulfino et al. (2013). Artificial pollination was carried out after emasculation and protection of developing female and male flowers. Elite J. curcas selected by the genetic breeding program of Instituto Agronômico de Campinas (IAC, Campinas, Brazil) was used as female parent in all crosses, while $J$. multifida and $J$. integerrima were used as male parents (for accession numbers see Tables 1 and 2). $F_{1}$ seeds from these crosses were germinated on appropriate recipients until transference to field conditions. Afterward, during the $F_{1}$ interspecific hybrids flowering, backcrosses were performed using J. curcas selected plants as recurring parental. For this step, we used female flowers of $J$. curcas and pollen of $F_{1}$ hybrids.

\section{Mitotic chromosome preparation}

For determination of parental genomic composition, root tips from both $\mathrm{F}_{1}$ or $\mathrm{BC}_{1} \mathrm{~F}_{1}$ potted seedlings or plants were pre-treated with $2 \mathrm{mM}$ 8-hydroxyquinolein (8-HQ) for $4.5 \mathrm{~h}$ at $18{ }^{\circ} \mathrm{C}$, fixed in methanol:acetic acid $(3: 1, \mathrm{v} / \mathrm{v})$ for at least $4 \mathrm{~h}$ and then stored at $-20^{\circ} \mathrm{C}$. Next, they were washed three times in distilled water and digested in a $2 \%$ cellulase (w/v, Onozuka R-10, Serva) and $20 \%$ pectinase (v/v, Sigma-Aldrich) solution for $4 \mathrm{~h}$ at $37^{\circ} \mathrm{C}$.

Slide preparation followed Carvalho and Saraiva (1993) with modifications introduced by Vasconcelos et al. 
Table 1 - Jatropha curcas/J. integerrima and J. curcas/J. multifida $\mathrm{F}_{1}$ hybrids, their backcrosses $\left(\mathrm{BC}_{1} \mathrm{~F}_{1}\right)$, and respective chromosome numbers.

\begin{tabular}{|c|c|c|c|}
\hline Interspecific cross (Accessions ${ }^{1}$ ) & Generation & Accession* & Number of $J$. curcas chromosomes/Total $(2 n)$ \\
\hline J. curcas/J. integerrima (L4P49/I2) & $\mathrm{F}_{1}$ & L4V64 & $11 / 22$ \\
\hline J. curcas/J. integerrima $(\mathrm{L} 2 \mathrm{P} 48 / \mathrm{I} 5)$ & & L3V50 & $11 / 22$ \\
\hline J. curcas/J. integerrima (L4P37/I1) & & L4V62 & $11 / 22$ \\
\hline J. curcas/J. multifida (L13P43/M7) & & L1V5 & $11 / 22$ \\
\hline J. curcas/J. multifida (L12P35/M7) & & L1V6 & $11 / 22$ \\
\hline J. curcas//J. curcas/J. integerrima (L4P49//L4P49/I2) & $\mathrm{BC}_{1} \mathrm{~F}_{1}$ & L4V1 & $19 / 22$ \\
\hline J. curcas//J. curcas/J. multifida (L3P18//R181) & & L3VE & $20 / 22$ \\
\hline
\end{tabular}

${ }^{1}$ Accessions from Instituto Agronômico de Campinas (IAC).

Table 2 - Pollen viability (\%) of Jatropha curcas/J. integerrima and $J$. curcas/J. multifida $\mathrm{F}_{1}$ hybrid accessions based on the staining with Alexander reagent (1980).

\begin{tabular}{lcccc}
\hline Interspecific cross $\left(\right.$ Accessions $\left.{ }^{1}\right)$ & Accession $\left(\mathrm{F}_{1}\right)^{2}$ & Number of analyzed pollen grains & Number of viable pollen grains & Pollen viability $(\%)$ \\
\hline J. curcas/J. integerrima $(\mathrm{L} 2 \mathrm{P} 34 / \mathrm{I} 4)$ & $\mathrm{L} 2 \mathrm{~V} 29$ & $2500 * *$ & 2074 & $83 \%$ \\
J. curcas/J. integerrima $(\mathrm{L} 5 \mathrm{P} 3 / \mathrm{I} 4)$ & L4V65 & $2500 * *$ & 2049 & $82 \%$ \\
J. curcas/J. multifida $(\mathrm{L} 12 \mathrm{P} 35 / \mathrm{M} 7)$ & L1V6 & $2500 * *$ & 1700 & $68 \%$ \\
\hline
\end{tabular}

${ }^{1}$ Accessions from the Instituto Agronômico de Campinas (IAC).

${ }^{2} 250$ pollen grains analyzed per slide, with 10 slides per accession.

(2010). Best slides were selected for staining in 4',6-diamidino-2-phenylindole (DAPI) $(2 \mu \mathrm{g} / \mathrm{mL})$ :glycerol $(1: 1$, $\mathrm{v} / \mathrm{v})$. Subsequently, they were destained in ethanol:glacial acetic acid $(3: 1, \mathrm{v} / \mathrm{v})$ for $30 \mathrm{~min}$ and transferred to absolute ethanol for $1 \mathrm{~h}$, both at room temperature. After air-dried, the selected slides were stored at $-20{ }^{\circ} \mathrm{C}$ until GISH and FISH experiments were performed.

\section{DNA probes and labeling}

For FISH procedures, the following probes were used: (1) R2, a $6.5 \mathrm{~kb}$ fragment containing the $18 \mathrm{~S}-5.8 \mathrm{~S}-$ 25S rDNA repeat unit from Arabidopsis thaliana (L.) Heynh. (Wanzenböck et al., 1997), and (2) D2, a 400 bp fragment containing two 5S rDNA repeat units from Lotus corniculatus L. [as L. japonicus (Regel) K.Larsen] (Pedrosa et al., 2002), which were labeled by nick translation with digoxigenin-11-dUTP (Roche Diagnostics) and biotin-11dUTP (Sigma), respectively.

For GISH analyses, genomic DNA was extracted according to Weising et al. (2005) and resuspended in Milli-Q water. Subsequently, DNA samples were treated with RNAse and quantified in $1 \%$ agarose gel. For probe labeling, genomic DNA samples of J. integerrima and $J$. multifida were labeled with digoxigenin-11-dUTP (Roche) by nick translation (Roche Diagnostics, Life Technologies). For blocking, non-labeled genomic DNA of $J$. curcas was fragmented (200-500 bp) by autoclaving.

\section{Fluorescent In Situ Hybridization (FISH) and Genomic In Situ Hybridization (GISH)}

Pre-treatments and post-hybridization washes were based on Pedrosa-Harand et al. (2009), in which the strin- gency wash was performed with 0.1 saline-sodium citrate (SSC) at $42{ }^{\circ} \mathrm{C}$. Chromosome and probe denaturation and detection were performed according to Heslop-Harrison et al. (1991). The hybridization mixture, containing 50\% formamide $(\mathrm{v} / \mathrm{v}), 2 \mathrm{SSC}, 10 \%$ dextran sulfate $(\mathrm{w} / \mathrm{v})$ and 5 $\mathrm{ng} / \mu \mathrm{L}$ of the probe, was denatured at $75^{\circ} \mathrm{C}$ for $10 \mathrm{~min}$. For the GISH preparations, J. curcas blocking DNA was also added to the hybridization mixture. Different probe:blocking ratios were tested for both hybrids (1:0 to 1:40 for $J$. integerrima:J. curcas, and 1:10 to 1:60 for J. multifida:J. curcas). For hybrid analyses, ratios of 1:40 and 1:60 were used for J. integerrima:J. curcas and J. multifida:J. curcas, respectively. Slides were denatured at $85^{\circ} \mathrm{C}$ for $7 \mathrm{~min}$. After GISH procedures, reprobing of slides for localization of $5 \mathrm{~S}$ and $35 \mathrm{~S}$ rDNA in the same cell was performed up according to Heslop-Harrison et al. (1992).

Digoxigenin-labelled probes were detected using sheep anti-digoxigenin-FITC (Roche Diagnostics) and amplified with donkey anti-sheep-FITC (Sigma), in 1\% (w/v) BSA. Biotin-labelled probes were detected with mouse anti-biotin (Dako), and the signal was visualized with rabbit anti-mouse TRITC conjugate (Dako), in 1\% (w/v) BSA. All preparations were counter-stained and mounted with 2 $\mu \mathrm{g} / \mathrm{mL}$ DAPI in Vector's Vectashield (1:1; v/v).

Images of the best cells were acquired using a Leica DMLB epifluorescence microscope and a Leica DFC 340FX camera with the Leica CW4000 software. Images were pseudocolored and optimized for contrast and brightness with Adobe Photoshop CS4 (Adobe Systems Incorporated) software. 


\section{Post-meiotic assays}

For post-meiotic analyses, flower buds were fixed in ethanol:glacial acetic acid $(3: 1, \mathrm{v} / \mathrm{v})$, for $6 \mathrm{~h}$ at room temperature and stored at $-20{ }^{\circ} \mathrm{C}$. Subsequently, anthers were digested in 2\% (w/v) cellulase Onozuka R-10 (Serva), 1\% $(\mathrm{w} / \mathrm{v})$ pectolyase (Sigma-Aldrich), and $1 \%(\mathrm{w} / \mathrm{v})$ cytohelicase (Sigma-Aldrich) for $4 \mathrm{~h}$ at $37^{\circ} \mathrm{C}$. Then, they were washed in distilled water, squashed and stained in $2 \%$ acetic carmine. Five slides were analyzed per hybrid. The quantities of the post-meiotic products (dyads, triads, tetrads, and polyads) were registered for the calculation of meiotic index, by dividing the normal tetrad number by the total post-meiotic products multiplied by 100 . Tetrads with four cells exhibiting uniform size were considered as normal post-meiotic products. On the other hand, dyads, triads, and polyads were considered abnormal.

For determination of pollen viability, flower buds in pre-anthesis were fixed in ethanol:glacial acetic acid (3:1, $\mathrm{v} / \mathrm{v})$, for $6 \mathrm{~h}$ at room temperature and stored at $-20^{\circ} \mathrm{C}$. Subsequently, anthers were transversally sectioned, and pollen grains were released in Alexander solution (Alexander, 1980) for staining and observation by light microscopy. Through this test, viable pollen presents the purple color in protoplasts and green in the cellulose wall, while nonviable grains stain only in green or blue. Ten slides were analyzed per hybrid: J. curcas/J. integerrima $\left(\mathrm{F}_{1}\right.$ : L2V29, L4V65) and J. curcas/J. multifida ( $\mathrm{F}_{1}$ : L1V6), with 250 pollen grain per slide totalizing 2,500 pollen units per hybrid.

\section{Results}

\section{GISH and FISH in mitotic chromosomes}

The $\mathrm{F}_{1}$ hybrids between $J$. curcas/J. integerrima and $J$. curcas/J. multifida presented no chromosomal loss in mitosis, maintaining the diploid chromosome number $(2 n=$ 22).

Application of GISH to interspecific Jatropha hybrids was possible in mitotic metaphases, although their cells have small, morphologically similar chromosomes. However, for some chromosomes, especially the less condensed prometaphase ones, hybridization of the late condensing subterminal regions was not possible. In such cases, the signals were restricted to terminal dots and the heterochromatic pericentromeric region (Figure 1A, B).

In regard to the three $J$. curcas $/ J$. integerrima $\mathrm{F}_{1}$ hybrids (L4V64, L3V50, and L4V62), the GISH evidenced that half of the chromosome set (11 chromosomes) was originated from $J$. integerrima, whereas the remaining $11 \mathrm{~J}$. curcas chromosomes remained unmarked, as expected for this generation (Figure 1A). From $J$. curcas chromosomes, one presented adjacent $5 \mathrm{~S}$ and $35 \mathrm{~S}$ rDNA sites (being the $35 \mathrm{~S}$ rDNA more distal), and two chromosomes had only terminal 35S rDNA, but different in size. From J. integerrima chromosomes, one had both $5 \mathrm{~S}$ and $35 \mathrm{~S}$ rDNA sites
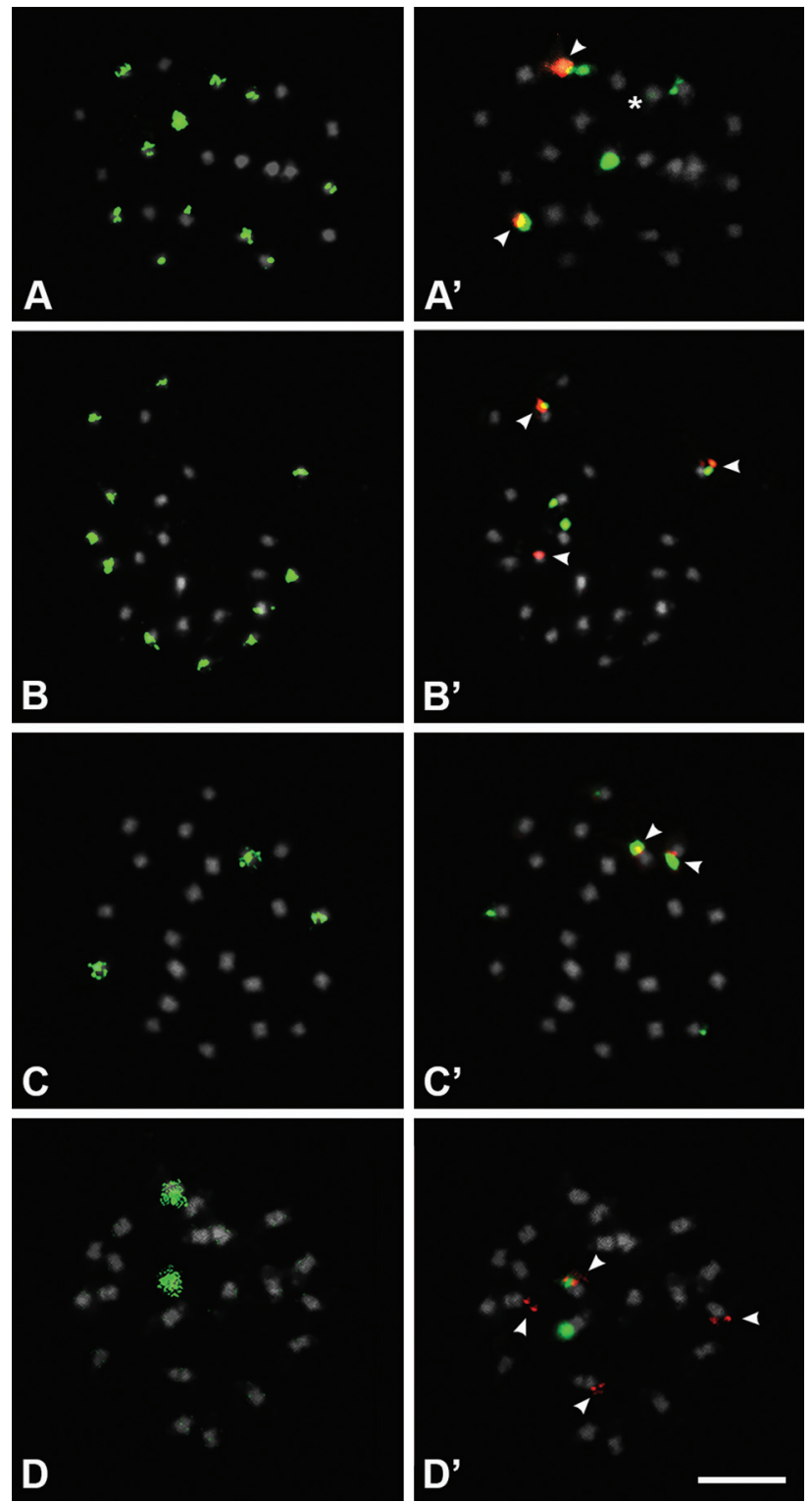

Figure 1 - Genomic In Situ Hybridization (GISH, A-D) and Fluorescent In Situ Hybridization (FISH, A'-D') in mitotic metaphases of hybrids between $J$. curcas and $J$. integerrima $(\mathbf{A}, \mathbf{C})$ and between $J$. curcas and $J$. multifida $(\mathbf{B}, \mathbf{D})$ generation $\mathrm{F}_{1}(\mathbf{A}, \mathbf{B})$ and $\mathrm{BC}_{1} \mathrm{~F}_{1}(\mathbf{C}, \mathbf{D})$. DAPI counterstained chromosomes (pseudocolored in gray), genomic probes (in green) of $J$. integerrima $(\mathbf{A}, \mathbf{C})$ and $J$. multifida $(\mathbf{B}, \mathbf{D})$. $(\mathbf{A}, \mathbf{B}) \mathrm{F}_{1}$ hybrids with 11 chromosomes from each parental, being those not marked of J. curcas. (C) $J$. curcas $/ / J$. curcas/J. integerrima $\mathrm{BC}_{1} \mathrm{~F}_{1}$, evidencing three $J$. integerrima chromosomes in green. (D) J. curcas//J. curcas/J. multifida $\mathrm{BC}_{1} \mathrm{~F}_{1}$, showing two $J$. multifida chromosomes in green. 5S rDNA (pseudocolored in red and indicated by arrowheads) and 35 rDNA (pseudocolored in green) (A'-D'). Asterisk in $\mathbf{A}^{\prime}$ indicate a faint rDNA site. Bar in $\mathbf{D}$ ' represents 5 $\mu \mathrm{m}$.

and another presented a smaller faint 35S rDNA (Figure $\left.1 A^{\prime}\right)$.

Likewise, the cells of the two hybrids of $J$. curcas/J. multifida of the $\mathrm{F}_{1}$ generation (L1V5 and L1V6) presented 11 chromosomes hybridized with $J$. multifida probe and 11 unmarked $J$. curcas chromosomes (Figure 1B). From $J$. curcas chromosomes, one presented adjacent $5 \mathrm{~S}$ and $35 \mathrm{~S}$ 
rDNA sites, two had only terminal $35 \mathrm{~S}$ rDNA, and one had only one terminal $5 \mathrm{~S}$ rDNA. From $J$. multifida chromosomes, only one had both $5 \mathrm{~S}$ and $35 \mathrm{~S}$ rDNA sites (Figure 1B').

In the cells of the $J$. curcas $/ / J$. curcas $/ J$. integerrima hybrid, in generation $\mathrm{BC}_{1} \mathrm{~F}_{1}$ (L4V1), the probe of $J$. integerrima hybridized to only three out of 22 chromosomes (Figure 1C), demonstrating that most chromosomes originated from $J$. curcas. From $J$. curcas chromosomes, one presented adjacent $5 \mathrm{~S}$ and $35 \mathrm{~S}$ rDNA sites (being the $35 \mathrm{~S}$ rDNA more distal), and three had only small terminal $35 \mathrm{~S}$ rDNA with different sizes. From $J$. integerrima chromosomes, only one had both $5 \mathrm{~S}$ and $35 \mathrm{~S}$ rDNA sites (Figure $\left.1 C^{\prime}\right)$.

Similarly, the $J$. multifida probe hybridized in only two of the 22 chromosomes of J. curcas//J.curcas/J. multifida hybrid in generation $\mathrm{BC}_{1} \mathrm{~F}_{1}$ ( $\left.\mathrm{L} 3 \mathrm{VE}\right)$, thus evidencing that the other 20 chromosomes originated from $J$. curcas (Figure 1D). From J. curcas chromosomes, one presented only terminal $35 \mathrm{~S}$ rDNA site, and three had only small terminal 5S rDNA site. From J. multifida chromosomes, only one had both $5 \mathrm{~S}$ and 35S rDNA sites (Figure 1D').

\section{Post-meiotic assays}

In the anthers of L2V29 and L4V65 ( $\mathrm{F}_{1}$ hybrids; $J$. curcas $/ J$. integerrima), a predominance of normal tetrads ( $90 \%$ and $85 \%$, respectively) was observed, although some tetrads with micronuclei were visualized in about 10 and $15 \%$ of the material analyzed, respectively (Figure 2). On the other hand, the L1V6 ( $\mathrm{F}_{1}$ hybrid; J. curcas/J. multifida) presented abnormal post-meiotic products, including tetrads with micronuclei, dyads, triads or polyads in $90 \%$ of the analyzed material (Figure 2A-C).

The pollen viability of both $\mathrm{F}_{1}$ hybrids of $J$. curcas/ $J$. integerrima (L2V29 and L4V65) varied from 82 to $83 \%$ (Table 2, Figure 2D-E), while viability was reduced to $68 \%$ in the $\mathrm{F}_{1}$ hybrid of $J$. curcas/J. multifida (L1V6).

\section{Discussion}

Although there is previous work on the parental genomic composition of $J$. curcas and $J$. integerrima interspecific hybrids (Fukuhara et al., 2016), this is the first cytogenetic study analyzing hybrids of $\mathrm{F}_{1}$ and $\mathrm{BC}_{1} \mathrm{~F}_{1}$ generations derived from a cross between J. curcas and J. multifida. Besides, the present work regards the second evaluation of parental genomic composition, post-meiotic behavior and pollen viability in Jatropha interspecific hybrids. Adjusted GISH methodology for Jatropha species enabled to increase efficiency in obtaining improved cultivars through interspecific crosses and assisted selection. Although Jatropha species have small chromosomes, the GISH technique allowed the distinction of chromosomes of both parental genomes in the here evaluated interspecific hybrids.
However, GISH pattern for Jatropha chromosomes appears mainly at pericentromeric region, probably due to their heterochromatic proximal condensation pattern $(\mathrm{Fu}-$ kuhara et al., 2016), in accordance to the $\mathrm{CMA}^{+}$(Chromomycin A3) heterochromatin distribution for $J$. curcas chromosomes, for instance (Marinho et al., 2018), indicating the preferential GISH for heterochromatic regions. The pericentromeric heterochromatin in J. curcas is constituted in part by Gypsy-type retrotransposon (Alipour et al., 2014). On the other hand, in $J$. integerrima and in $J$. multifida species, the heterochromatic $\mathrm{CMA}^{+}$pattern is restricted to 35S rDNA sites (Marinho et al., 2018). Additionally, terminal dots in $J$. curcas probably correspond to JcSat1 J. curcas satellite DNA sequence (Fukuhara et al., 2016) or to Copia-type elements as described previously (Alipour et al., 2013). However, no terminal heterochromatic dots were found for J. integerrima or J. multifida chromosomes (Marinho et al., 2018), as was corroborated by the absence of dot sites by GISH for chromosomes of both species in $F_{1}$ hybrids in the present work and by Fukuhara et al. (2016) for J. curcas x J. integerrima hybrids. Previous work with GISH on species with small chromosomes also showed preferential in situ hybridization in regions rich in repetitive DNA, as observed in Arachis (Seijo et al., 2007) and Cucumis (Zhang et al., 2015).

Regardless of the pollen donor species ( $J$. integerrima or J. multifida), the here evaluated $\mathrm{F}_{1}$ hybrids showed the expected chromosome number in mitotic metaphases (11 chromosomes originating from each parental), resulting in a normal diploid number $(2 n=22)$ in all analyzed cells. Additionally, for both $\mathrm{F}_{1}$ hybrids, one carrier $5 \mathrm{~S}$ and 35S rDNA chromosome were identified per genome as expected (see Marinho et al., 2018). However, for J. curcas/J. integerrima two 35 rDNA carrier chromosomes were observed for the $J$. curcas chromosomes and one chromosome with a faint site was observed for the $J$. integerrima instead of one per genome as expected (see Marinho et al., 2018). Also, for J. curcas/J. multifida, both $35 \mathrm{rDNA}$ carrier chromosomes were from J. curcas. These data indicate that, despite the apparently mitotic stability for both $\mathrm{F}_{1}$ hybrids, there was an apparently preferential presence of the 35 rDNA carrier $J$. curcas chromosomes for both $\mathrm{F}_{1}$ hybrids. Additionally, the extra $35 \mathrm{rDNA}$ faint site for $J$. curcas $/ J$. integerrima and the extra 5 rDNA site for $J$. curcas $/ J$. multifida indicate chromosome rearrangement events for both hybrids and possible unbalanced chromosomes.

Previous data for the hybrids analyzed revealed only $21.1 \%$ fruit yield rate for the crosses between J. curcas and $J$. integerrima, indicating a high abortion rate, although the germination of the hybrid in question was high $(83.5 \%)$ (Rulfino et al., 2013). Regarding J. multifida, the observed incompatibility was still higher; of the 582 crosses conducted, only 45 fruits were produced (7.6\% success), and only four seeds germinated. According to Moreira et al. 


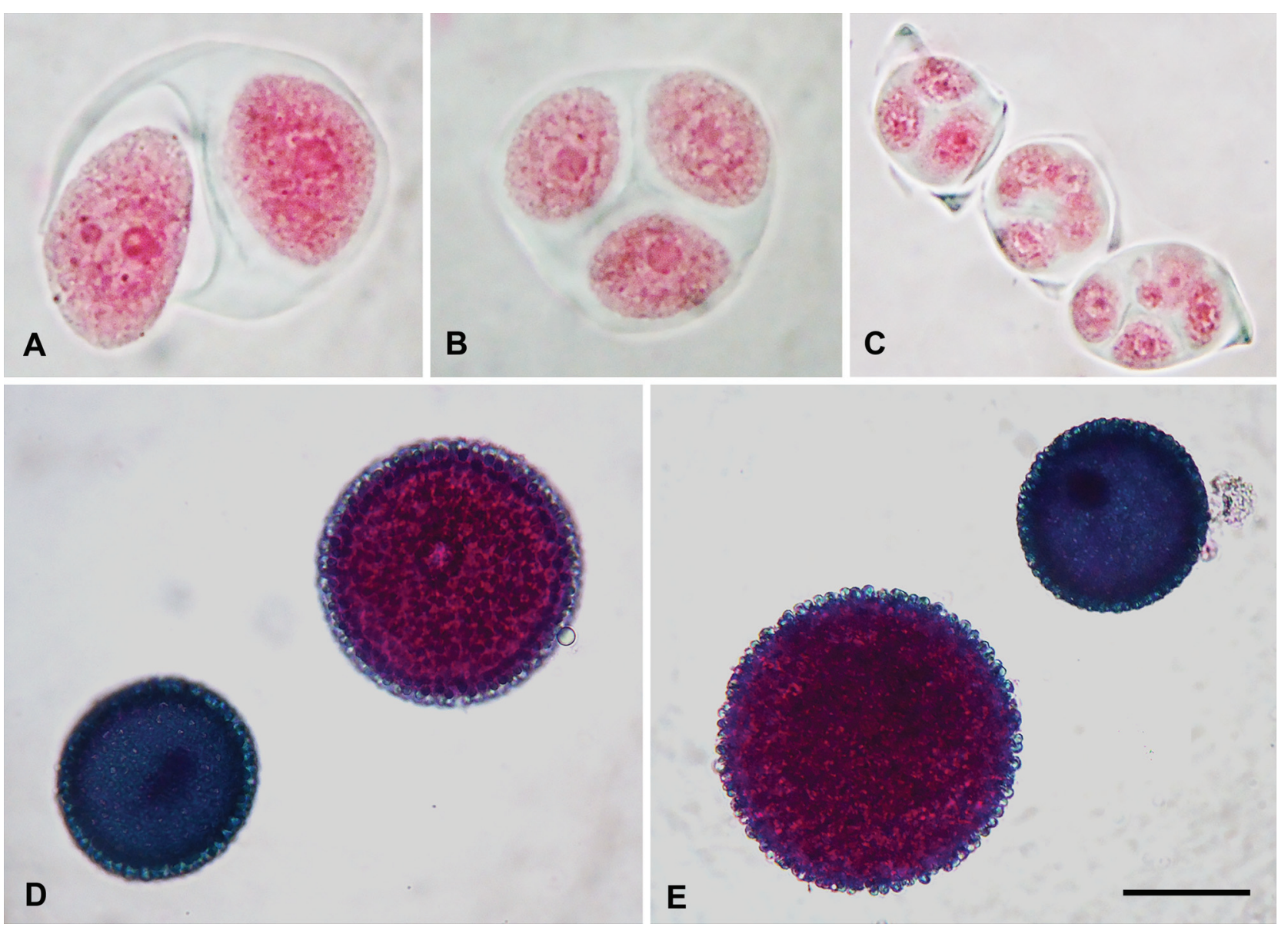

Figure 2 - Pollen viability and post-meiotic stage (tetrad formation) analysis in Jatropha hybrids and related species in the $\mathrm{F}_{1}$ generation, L1V6 accession (J. curcas/J. multifida) (A, B, D), L2V29 (J. curcas/J. integerrima) $(\mathbf{C}, \mathbf{E})$. (A, B, C) Post-meiotic phases stained with $2 \%$ Carmine acetic with formation of (A) dyad, (B) triads and (C) unbalanced tetrads with nuclei of distinct sizes. (D, E) Pollens stained with reactive of Alexander (1980), in pink, viable pollen and, in blue, infeasible pollen. Bar in $\mathbf{E}$ represents $5 \mu \mathrm{m}$.

(2013), the low fruit index derived from these crosses resulted in post-zygotic genetic incompatibility.

Morphological features observed in both $\mathrm{F}_{1}$ interspecific hybrids were intermediate between female ( $J$. curcas) and male ( $J$. integerrima or $J$. multifida) parental species (Rulfino et al., 2013), corroborating GISH results related to parental chromosome distribution (i.e., 11 chromosomes for each parental). The morphological variability observed in $\mathrm{F}_{1}$ population was high for both interspecific hybridization assays. For instance, J. curcas/J. integerrima population presented plants with variation in size (dwarf, semi-dwarf, medium and high), leaf pigmentation and shape (anthocyanin), flower coloration (light pink to purple), size and number of female and male flowers (Figure S1). Similarly, the morphological traits of J. curcas/J. multifida plants were also intermediate showing, e.g., seven leaf lobes in the $\mathrm{F}_{1}$ hybrid which is intermediate of $J$. curcas (five) and J. multifida (nine) (Figure S2). Flower colors of these interspecific hybrids were also different from the male and female parental (Figures S1, S2).
On the other hand, concerning reproductive structures, all $\mathrm{F}_{1}$ hybrids showed similarity with the male parental (J. multifida or $J$. integerrima) (Rulfino et al., 2013). Pollen viability of $J$. curcas $/ J$. integerrima $\mathrm{F}_{1}$ hybrids was high ( 82 to $83 \%$ ) in the present work, higher than previous reported for $J$. curcas $(77 \%)$ and J. integerrima $(72.5 \%)$ species (Rufino et al., 2013). It allowed the advancement of generations, with a high rate of seed formation in $\mathrm{BC}_{1} \mathrm{~F}_{1}$ generation (J. curcas $/ / J$. curcas $/ J$. integerrima), with $31 \%$ pollen-fruit setting and $85.9 \%$ seed germination, due to higher genetic compatibility between $J$. curcas and plants of the $\mathrm{F}_{1}$ generation. However, the post-germination survival rate was low (38.9\%) (Rufino et al., 2013), probably due to the expression of damaging alleles in $\mathrm{BC}_{1} \mathrm{~F}_{1}$ plants. In contrast, low rates were found for these hybrids in previous studies, with respect to pollen viability of $F_{1}$ hybrids (average rate of $48.4 \%$ ), probably associated to several meiotic abnormalities observed (Fukuhara et al., 2016), which presented low frequency in the present work (10$15 \%)$. The same situation applies to the seed setting in $\mathrm{F}_{2}$ hybrids of $J$. curcas/J. integerrima (Sujatha and Praba- 
karan, 2003; Parthiban et al., 2009; Muakrong et al., 2014), as compared with the present results. Such divergent results may be related to the different genotypes used in the crosses of both works or, still, to environmental factors. According to Müller et al. (2016), sexual reproduction is very sensitive to environmental perturbations, and pollen viability can vary accordingly under high temperature and in thermotolerant genotypes, as observed for cultivated tomato (Solanum lycopersicum).

In turn, the pollen viability observed in the $\mathrm{F}_{1}$ hybrid of $J$. curcas/J. multifida was relatively low (68\%), but similar to observed previously for J. multifida species (68\%) (Rulfino et al., 2013). This reduction in viability may be directly associated with the observed meiotic irregularities of this hybrid (L1V6, $\mathrm{F}_{1} J$. curcas/J. multifida), especially considering post-meiotic irregularities, such as the formation of dyads, triads, polyads and micronuclei, compromising the pollen viability and possibly leading to a reduction of vigor and fertility (Fuzinatto et al., 2008; Reis et al., 2008). According to Rulfino et al. (2013), the male flowers of the $\mathrm{F}_{1}$ hybrid resulting from the crossing with J. multifida generated smaller pollen grains, not visible to the naked eye. Despite this, these plants were used to pollinate female flowers of $J$. curcas, allowing the production of the $\mathrm{BC}_{1} \mathrm{~F}_{1}$, but with low of fruit setting (7.6\%) and seed germination (8.8\%) rates (Rulfino et al., 2013). The resulting meiosis behavior observed in the present work may explain the inferior performance of this interspecific cross and is in accordance to their phylogenetic distance (Sudheer Pamidiamarri et al., 2008).

Both $\mathrm{BC}_{1} \mathrm{~F}_{1}$ interspecific hybrids here evaluated $(J$. curcas//J. curcas/J. integerrima and J. curcas $/ / J$. curcas/J. multifida) exhibited 22 chromosomes in all analyzed mitotic metaphases, suggesting that only $n=11$ gametes were feasible for the formation of the new generation, although the formation of aneuploid microspores for $J$. curcas/ $J$. integerrima $\mathrm{F}_{1}$ hybrids was reported by Fukuhara et al. (2016). In the present work, a preferential presence of $J$. curcas chromosomes for both $\mathrm{BC}_{1} \mathrm{~F}_{1}$ hybrids was observed, as previously reported to $S_{1}$ individuals obtained by selfpollination of $J$. curcas/J. integerrima $\mathrm{F}_{1}$ (Fukuhara et al., 2016). Only two or three alien chromosomes were observed in $\mathrm{BC}_{1} \mathrm{~F}_{1}$ plants, differing from the expected number $(11+5$ or 6 from J. curcas and 5 or 6 from related species), probably because this species was used as a recurrent female parent, both in the present work and in Fukuhara et al. (2016). However, we cannot infer if the preferential transmission was affected by cytoplasmic factors, because no reciprocal crosses were performed in the present work. Additionally, for $J$. curcas $/ / J$. curcas/J. multifida, the three extra $5 \mathrm{~S}$ rDNA sites in separate chromosomes, besides single carrier 5S-35S rDNA and 35S rDNA chromosomes indicate chromosome rearrangements.

A higher number of $J$. curcas chromosomes in $\mathrm{BC}_{1} \mathrm{~F}_{1}$ resulted in plants with more similar phenotypes to this pa- rental species. In $J$. curcas/ $J$. integerrima hybrids (including those studied in this work, L4P49 e L3P18), for example, most of the $\mathrm{BC}_{1} \mathrm{~F}_{1}$ hybrids $(90 \%)$ presented leaves with the characteristic pentagonal form ("curcas type"), whereas in few individuals the leaves were lanceolate (Figure S3), similar to J. integerrima (Rulfino et al., 2013). This similarity with $J$. curcas seems to reflect the loss of most $J$. integerrima chromosomes in this generation. Other features deserve mentioning, such as flower and seed color, fruit shape, number of female flowers, number of fruits per bunch, number of bunches per plant, resistance to pests and diseases, oil content and quality, phorbol esters contents, which were quite variable among plants of the $\mathrm{BC}_{1} \mathrm{~F}_{1}$ generation (unpublished data). The lower size (dwarf) characteristic of J. integerrima male parental and erect growth (characteristic of the female parental $J$. curcas) also segregated in the $\mathrm{BC}_{1} \mathrm{~F}_{1}$ population (Rulfino et al., 2013). However, most of the obtained hybrids had phenotypic characteristics closer to the female parental $(J$. curcas).

Similarly, the few and unpublished $\mathrm{BC}_{1} \mathrm{~F}_{1}$ hybrids generated from the cross between J. curcas and J. multifida showed greater resemblance with the recurrent parental $J$. curcas, although characteristics as fruit shape, seed and oil yield, phorbol esters content presented interesting variability (progenies under investigation). It should be noted that most of the hybrids obtained, including those studied in the present work (Table 1), exhibited phenotypic characteristics closer to the female parental $J$. curcas than that of the parent pollen donors ( $J$. integerrima or J. multifida), corroborating the higher number of chromosomes of $J$. curcas observed after GISH analyzes.

Continuous selection of plants with characteristics of interest among the backcrossing hybrids $\left(\mathrm{BC}_{1} \mathrm{~F}_{1}\right)$ may result in plants with agronomical interesting features in medium to long term. For instance, the selection of lower size plants with introduced (alien) chromosomes of $J$. integerrima can be promising for the production of viable cultivars to the mechanized harvest, with consequent reduction of production costs. In this sense, GISH can help in the future characterization and selection of the best genotypes, aiming at the advance and planning of the next crosses towards a stable $J$. curcas cultivar.

Despite the meiotic abnormalities found in the $\mathrm{F}_{1}$ generation and the reduction of pollen viability, especially for the crossing of J. curcas/J. multifida, the number of regular pollen grains was sufficient to allow generation advance $\left(\mathrm{BC}_{1} \mathrm{~F}_{1}\right)$ with hybrids bearing a stable chromosomal number $(2 n=22)$ equal to the parental individuals for all analyzed mitotic metaphases. This indicates that only gametes with $n=11$ chromosomes were feasible for the formation of the new generation, but chromosome rearrangement events could be detected using rDNA chromosome markers, suggesting unbalanced cells. On the other hand, GISH results uncovered that $\mathrm{BC}_{1} \mathrm{~F}_{1}$ hybrid individuals presented a higher 
number of chromosomes from $J$. curcas recurrent parental than expected, indicating a preferential transmission of chromosomes from this species.

\section{Acknowledgments}

The authors thank Coordenação de Aperfeiçoamento de Pessoal de Nível Superior - Brasil (CAPES) - Finance Code 001 and CNPq (Brazilian National Council for Scientific and Technological Development) for valuable financial support and fellowships. We are also grateful to Brazilian Petroleum Corporation PETROBRÁS for the financial support to the research carried out at the Instituto Agronômico de Campinas (IAC).

\section{Conflict of Interests}

There are no conflicts of interest.

\section{Author Contributions}

ACBV, DAM, WJS and AMBI conceived the study; RCS, MMCF and ARSO conducted the experiments; RCS, DAM, ARSO and ACBV analyzed the data; RCS, DAM, WJS, AMBI and ACBV wrote the manuscript; all authors read and approved the final version.

\section{References}

Alexander MP (1980) A versatile stain for pollen, fungi, yeast and bacteria. Stain Tech 55:13-18.

Alipour A, Tsuchimoto S, Sakai H, Ohmido N and Fukui K (2013) Structural characterization of copia-type retrotransposons leads to insights into the marker development in a biofuel crop, Jatropha curcas L. Biotechnol Biofuels 6:129.

Alipour A, Cartagena JA, Tsuchimoto S, Sakai H, Ohmido N and Fukui K (2014) Identification and characterization of novel gypsy-type retrotransposons in a biodiesel crop, Jatropha curcas L. Plant Mol Biol Rep 32:923-930.

Banerji R, Chowdhury AR, Misra G, Sudarsanam G, Verma SC and Srivastava GS (1985) Jatropha seed oils for energy. Biomass 8:277-282.

Basha SD and Sujatha M (2007) Inter and intra-population variability of Jatropha curcas (L.) characterized by RAPD and ISSR markers and development of population-specific SCAR markers. Euphytica 156:375-386.

Brasileiro BG, Dias DCFS, Bhering MC and Dias LAS (2012) Floral biology and characterization of seed germination in physic nut (Jatropha curcas L.). Rev Bras Sementes [online] 34:556-560.

Carels N (2013) Towards the Domestication of Jatropha: The Integration of Sciences. In: Bahadur B, Sujatha M and Carels N (eds) Jatropha, Challenges for a New Energy Crop. Springer, New York, pp 263-299.

Carvalho CR, Clarindo WR, Praça MM, Araújo FS and Carels N (2008) Genome size, base composition and karyotype of Jatropha curcas L., an important biofuel plant. Plant Sci 174:613-617.
Carvalho CR and Saraiva LS (1993) An air-drying technique for maize chromosomes without enzymatic maceration. Biotech Histochem 68:142-145.

Chang-Wei L, Kun L, You C and Young-Yu S (2007) Floral display and breeding system of Jatropha curcas L. For Stud China 9:114-119.

de Argollo Marques D, Siqueira WJ, Colombo CA and Ferrari RA (2013) Breeding and Biotechnology of Jatropha curcas. In: Bahadur B, Sujatha M and Carels N (eds) Jatropha, Challenges for a New Energy Crop. Springer, New York, pp 457-478.

Díaz BG, Argollo DM, Franco MC, Nucci, SM, Siqueira WJ, Laat DM and Colombo CA (2017) High genetic diversity of Jatropha curcas assessed by ISSR. Genet Mol Res 16:gmr16029683.

Divakara BN, Upadhyaya HD, Wani SP and Laxmipathi Gowda CL (2010) Biology and genetic improvement of Jatropha curcas L.: a review. Appl Energy 87:732-742.

Fukuhara S, Muakrong N, Kikuchi S, Tanya P, Sassa H, Koba T and Srinives P (2016) Cytological characterization of an interspecific hybrid in Jatropha and its progeny reveals preferential uniparental chromosome transmission and interspecific translocation. Breed Sci 66: 838-844.

Fuzinatto VA, Pagliarini MS and Valle CB (2008) Evaluation of microsporogenesis in an interspecific Brachiaria hybrid (Poaceae) collected in distinct years. Genet Mol Res 7:42432.

Grewal S, Yang C, Edwards SH, Scholefeld D, Ashling S, Burridge AJ, King IP and King J (2018) Characterisation of Thinopyrum bessarabicum chromosomes through genomewide introgressions into wheat. Theor App Genet 131:389406.

Heslop-Harrison JS, Schwazarcher T, Anamthawat-Jónsson K, Leitch AR and Shi M (1991) In situ hybridization with automated chromosome denaturation. Technique 3:109-115.

Heslop-Harrison JS, Harrison GE and Leitch IJ (1992) Reprobing of DNA: DNA in situ hybridization preparations. Trends Genet 8:372-373.

Jones N and Miller JH (1991) Jatropha curcas: A multipurpose species for problematic sites. Land Resour Ser 1:1-12.

Laosatit K, Tanya P, Muakrong N and Srinives P (2014) Development of interspecific and intergeneric hybrids among jatropha-related species and verification of the hybrids using EST-SSR markers. Plant Genet. Resour. 12:58-61.

Laosatit K, Naratid M, Patcharin T and Peerasak S (2017) Overcoming crossing barriers between jatropha (Jatropha curcas L.) and castor bean (Ricinus communis L.) Crop Breed Appl Biotechnol 17:164-167.

Li H, Tsuchimoto S, Harada K, Yamasaki M, Sakai H, Wada N, Alipour A, Sasai T, Tsunekawa A, Tsujimoto H et al. (2017) Genetic tracing of Jatropha curcas L. from its Mesoamerican origin to the world. Front Plant Sci 8:1539.

Liu Z, Seiler GJ, Gulya TJ, Feng J, Rashid KY, Cai X and Jan C-C (2017) Triploid production from interspecific crosses of two diploid perennial Helianthus with diploid cultivated sunflower (Helianthus annuus L.). G3 (Bethesda) 7:1097-1108.

Marinho ACTA, Vasconcelos S, Vasconcelos EV, Marques DA, Benko-Iseppon AM and Brasileiro-Vidal AC (2018) Karyotype and genome size comparative analyses among six species of the oilseed-bearing genus Jatropha (Euphorbiaceae). Gen Mol Biol 41:442-449. 
Montes JM and Melchinger AE (2016) Domestication and breeding of Jatropha curcas L. Trends Plant Sci 21:10451057.

Montes MJ, Technow F, Martin M and Becke K (2014). Genetic diversity in Jatropha curcas L. assessed with SSR and SNP markers. Diversity (Basel) 6:551-566.

Montes Osorio LR, Torres Salvador AF, Jongschaap REE, Azurdia Perez CA, Berduo Sandoval JE, Trindade LM, Visser RG and van Loo EM (2014) High level of molecular and phenotypic biodiversity in Jatropha curcas from Central America compared to Africa, Asia and South America. BMC Plant Biol 14:77.

Moreira MF, Marques DA, Ventrella MC, Rulfino ER, Siqueira WJ, Franco MC, Scott MDS and Nicomedes Júnior J (2013) Rescate embrionario in vitro en el cruzamiento de Jatropha curcas con J. integerrima, J. multifida y J. podagrica. In: Congreso Internacional sobre Biocombustibles, Veracruz/México. Energia Alterna y Biocombustibles: Innovación y invertigación para un desarollo sustentable. pp. 119-127.

Muakrong N, One KT, Tanya P and Srinives P (2014) Interspecific jatropha hybrid as a new promising source of woody biomass. Plant Genet. Resour 12:S17-S20.

Müller F, Xu J, Kristensen L, Wolters-Arts M, Groot PFM, Jansma SY, Mariani C, Park S and Rieu I (2016) High-temperature-induced defects in tomato (Solanum lycopersicum) anther and pollen development are associated with reduced expression of B-class floral patterning genes. PLOS One 9:1-14.

One KT, Muakrong N, Phetcharat C, Tanya P and Srinives P (2014) Inheritance of dwarfness and erect growth habit in progenies of Jatropha curcas Jatropha integerrima. J Am Soc Hortic Sci 139:582-586.

Pagliarini MS (2000) Meiotic behavior of economically important plant species: the relationship between fertility and male sterility. Genet Mol Biol 23:997-1002

Parthiban KT, Kumar RS, Thiyagarajan P, Subbulakshmi V, Vennila S and Rao MG (2009) Hybrid progenies in jatropha - a new development. Curr Sci 96:815-823.

Pazeto MSR, Unêda-Trevisoli SH, Corrêa AAP, Vianna VF Leite DC and Di Mauro AO (2015) Genetic diversity in Jatropha species from different regions of Brazil based on morphological characters and inter-simple sequence repeat (ISSR) molecular markers. Afr J Biotechnol 14:2066-2079.

Victor Pecina-Quintero V, Anaya-López JL, Zamarripa-Colmenero A, Núñez-Colín CA, Montes-García N, Solís-Bonilla JL and Jiménez-Becerril MF (2014). Genetic structure of Jatropha curcas L. in Mexico and probable center of origin. Biomass Bioenergy 60:147-155.

Pedrosa A, Sandal N, Stougaard J, Schweizer D and Bachmair A (2002) Chromosomal map of the model legume Lotus japonicus. Genetics 161:1661-1672.

Pedrosa-Harand A, Kami J, Geffroy V, Gepts P and Schweizer D (2009) Cytogenetic mapping of common bean chromosomes reveals a less compartmentalized small-genome plant species. Chromos Res 17:405-417.

Popluechai S, Breviario D, Mulpuri S, Makkar HPS, Raorane M, Reddy AR, Palchetti E, Gatehouse AMR, Syers KJ, O'Donnell AG et al. (2009) Narrow genetic and apparent phenetic diversity in Jatropha curcas: initial success with generating low phorbol ester interspecific hybrids. Nat Precedings, http://hdl.handle.net/10101/npre.2009.2782.1
Ramzan F, Younis A and Lim K-B (2017) Application of genomic in situ hybridization in horticultural science. Int J Genomics, 2017:7561909.

Reis CAO, Schifino-Wittmann MT and DallAgnol M (2008) Chromosome numbers, meiotic behavior and pollen fertility in a collection of Paspalum nicorae Parodi accessions. Crop Breed Applied Biotech 8:212-218.

Rulfino ER, Siqueira WJ, Argollo-Marques D, Franco MC, Scott MDS, Carqueijo AP, Colombo CA, Moreira MF and Nicomedes Junior J (2013) Obtención de híbridos interespecíficos de Jatropha curcas L. In: Vázquez AP and Pérez EG (eds) Energia Alterna y Biocombustibles: Innovación y Investigación para un Desarollo Sustentable. Germoplasma y Mejoramiento Genético. Fundación Colegio de Postgraduados en Ciencias Agrícolas A.C., Texcoco, pp 107-117.

Santos DN, Ferreira JL, Pasqual M, Generoso AL, Setotaw TA, Cançado GM and Vendrame WA (2016) Population structure of Jatropha and its implication for the breeding program. Genet Mol Res 15:1-11.

Sasikala R and Paramathma M (2010) Chromosome studies in the genus Jatropha L. Electron J Plant Breeding 4:637-642

Seijo G, Lavia GI, Fernández A, Krapovickas A, Ducasse DA, Bertioli DJ and Moscone EA (2007) Genomic relationships between the cultivated peanut (Arachis hypogaea, Leguminosae) and its close relatives revealed by double GISH. Am J Bot 94:1963-1971.

Sinha P, Islam MA, Negi MS and Tripathi SB (2016) Analysis of genetic diversity and fatty acid composition in a prebreeding material of Jatropha. J Plant Biochem Biotechnol 25:111116.

Souza EH, Souza FVD, Rossi ML, Packer RM, Cruz-Barros MAV and Martinelli AP (2017) Pollen morphology and viability in Bromeliaceae. An Acad Bras Cienc 89:3067-3082.

Sudheer PD, Mastan SG, Rahman H, Prakash ChR Singh S and Reddy MP (2011) Cross species amplification ability of novel microsatellites isolated from Jatropha curcas and genetic relationship with sister taxa: cross species amplification and genetic relationship of Jatropha using novel microsatellites. Mol Biol Rep 38:1383-1388.

Sudheer Pamidiamarri DVN, Nirali P, Reddy MP and Radhakrishnan T (2008) Comparative study of interspecific genetic divergence and phylogenic analysis of genus Jatropha by RAPD and AFLP. Mol Biol Rep 36:901-907.

Sujatha M (1996) Genetic and tissue culture studies in castor (Ricinus communis L.) and related genera. B.Sc. Thesis, Osmania University, Hyderabad, 295 p.

Sujatha M (2013) Genetic diversity, Molecular Marker and Marker assisted Breeding in Jatropha. In: Bahadur B, Sujatha M, Carels N (eds) Jatropha, Challenges for a New Energy Crop. Springer, New York, pp 395-422.

Sujatha M and Prabakaran AJ (2003). New ornamental Jatropha hybrids through interspecific hybridization. Genet Resour Crop Ev 50:75-82.

Tanya P, Taeprayoon P, Hadkam Y and Srinives P (2011). Genetic diversity among Jatropha and Jatropha related species based on ISSR markers. Plant Mol Biol Report 29:252-264.

Wanzenböck EM, Schöfer C, Schweizer D and Bachmair A (1997) Ribosomal transcription units integrated via T-DNA transformation associate with the nucleolus and do not require upstream repeat sequences for activity in Arabidopsis thaliana. Plant J 11:1007-1016. 
Weising K, Nybom H, Wolff K and Kahl G (2005) DNA Fingerprinting in Plants: Principles, Methods and Applications. 2nd edition. CRC Press, Boca Raton, 472 p.

Younis A, Ramzan F, Hwang YJ and Lim KB (2015) FISH and GISH: molecular cytogenetic tools and their applications in ornamental plants. Plant Cell Rep 34:1477-1488.

Zhang Y, Cheng C, Li J, Yang S, Wang Y, Li Z, Chen J and Lou Q (2015) Chromosomal structures and repetitive sequences divergence in Cucumis species revealed by comparative cytogenetic mapping. BMC Genomics 16:730.

\section{Supplementary material}

The following online material is available for this article:

Figure S1 - F1 interspecific hybrid of the cross between $J$. curcas (O) and J. integerrima $\left(\mathrm{O}^{\prime \prime}\right)$.

Figure S2 - Interspecific cross between $J$. curcas (ㅇ) and $J$. multifida $\left(\mathrm{O}^{\prime}\right)$.

Figure S3 - BC1F1 Interspecific hybrid of cross between F1 (J. curcas/J. integerrima) and J. curcas.

$$
\text { Associate Editor: Dario Grattapaglia }
$$

License information: This is an open-access article distributed under the terms of the Creative Commons Attribution License (type CC-BY), which permits unrestricted use, distribution and reproduction in any medium, provided the original article is properly cited. 